\title{
Evaluation of the Protective Effect of Moringa oleifera Leaf Extract against Aluminium Induced Liver Damage in Male Albino Wistar Rats
}

\author{
Edet Okon Akpanyung ${ }^{1}$, Dennis Uju Nwaokonko1, Moses \\ Bassey Ekong 2, Mfon Monday Ekpo ${ }^{2}$
}

\author{
${ }^{1}$ Department of Biochemistry, University of Uyo, Uyo, Akwa Ibom State, Nigeria \\ ${ }^{2}$ Department of Anatomy, University of Uyo, Uyo, Akwa Ibom State, Nigeria
}

\begin{abstract}
Aluminium is a hepatotoxic element that is extensively used in the production of household cookware, storage utensils, water purification and in the preparation of some drugs. Conversely, the leaf extract of Moringa oleifera is hepatoprotective amongst other medicinal and nutritional benefits. The present study evaluated the protective effect of ethanol leaf extract of Moringa oleifera on Aluminium induced hepatotoxicity in male albino wistar rats. Eighteen (18) male albino wistar rats weighing between 140 and $180 \mathrm{~g}$ were divided into 3 groups of 6 animals per group. Group 1 served as control and was given normal rat chow and distilled water; Group 2 was administered $100 \mathrm{mg}$ of Aluminium chloride per $\mathrm{kg}$ body weight whereas animals in Group 3 received $300 \mathrm{mg} / \mathrm{kg}$ body weight of ethanol leaf extract of Moringa oleifera and $100 \mathrm{mg}$ per $\mathrm{kg}$ body weight of Aluminium chloride by oral gavage. The rats were sacrificed after 28 days of treatment. Blood and liver samples were obtained and used for the analyses of some marker enzymes (ALP, AST, ALT); haematological indices; lipid profile and histopathological assessment using standard techniques. The results show that Aluminium chloride increased the activities of ALP, ALT and AST significantly $(\mathrm{P}<0.05)$. TC, TG and LDL also increased significantly whereas HDL showed a significant decrease $(\mathrm{P}<0.05)$. The $\mathrm{RBC}$ count, $\mathrm{Hb}, \mathrm{PCV}$, lymphocytes and platelets decreased while WBC count and neutrophils increased significantly $(\mathrm{P}<0.05)$. Aluminium chloride caused alterations in the normal histology of the hepatocytes consistent with observed changes in enzyme activities. Administration of ethanol leaf extract of Moringa oleifera moderated the deleterious effects of Aluminium chloride.
\end{abstract}

Keywords: Aluminium, Enzymes, Haematology, Histopathology, Lipid, Moringa

\subsection{Introduction}

Moringa oleifera belongs to the Moringaceae family of perennial angiosperm plants. It is a fast growing tree that can attain a height of about $10-12 \mathrm{~m}$ with a diameter of about $45 \mathrm{~cm}$ (Bosch, 2004; Parrotta, 2005). Although native to the Sub-Himalayan tracts of India, Pakistan, Bangladesh and Afghanistan, it is now cultivated throughout the tropical and subtropical regions of the world because of its numerous benefits (Odee, 1998; Anwar and Bhanger, 2003; Hsu et al., 2006). In Nigeria, Moringa oleifera is planted in all parts of the country and is identified by a variety of local names incuding, 'Zogale' (Hausa); 'ewe igbale' (Yoruba) and 'ikwa oyibo' (Ibo) (Thilza et al., 2010). The leaves, fruit, flowers and immature pods of Moringa oleifera are highly nutritious and have also been utilized in ethnomedicine for the treatment of various human ailments (Anwar et al., 2007; Kumar et al., 2010). Specifically, the leaves are reported to be rich in proteins, mineral elements, vitamins $\mathrm{A}, \mathrm{C}, \mathrm{E}, \beta$-carotene, various polyphenolic compounds and natural antioxidants (Amaglo et al., 2010; Karthivashan et al., 2013). Moreover, a variety of pharmacological activities have been attributed to the leaf extract of Moringa including anticancer, antiinflamatory, bactericidal, hypocholesterolemic, antiatherosclerotic, antioxidant, neuro and hepatoprotective (Buraimoh, 2011; Peixoto et al., 2011; Saalu et al., 2012; El-bakry et al 2016; Ekong et al., 2017).

Aluminium is the third most abundant element constituting about $8 \%$ of the total mineral components of the earth's crust (WHO, 2010). The element is an essential component of medications such as antacids, vaccines, phosphate binders (Kaechny et al.,1997; Exley, 1998); water purification agents (Newairy et al., 2009); food additives (Yokel, 2000) and tooth paste (Abbasali et $a l, 2005)$. Aluminium is also used extensively in the

This article is published under the terms of the Creative Commons Attribution License 4.0

Author(s) retain the copyright of this article. Publication rights with Alkhaer Publications.

Published at: http://www.ijsciences.com/pub/issue/2018-02/

DOI: 10.18483/ijSci.1520; Online ISSN: 2305-3925; Print ISSN: 2410-4477 
manufacture of various household cookware and storage utensils (Sorenson et al., 1974). Therefore, its abundance and widespread use underscores the potential for human exposure and susceptibility to harm (Zhang and Zhou, 2005). Most individuals ingest $1-10 \mathrm{mg}$ of Aluminium per day (Greger, 1992) mainly through the oral route and by inhalation (Hanchez-Leroy, 2013). In adults, the tolerable weekly intake of Aluminium is $7 \mathrm{mg} / \mathrm{kg}$ bw (WHO/FAO, 1989). However, this tolerable limit can be exceeded as a consequence of continuous exposure (Gauthier et al., 2000). Aluminium could be toxic if ingested in amounts greater than $40 \mathrm{mg} /$ day (Dolara, 2014). The liver is one of the target organs for Aluminium toxicity (Klein et al., 1984; Galle et al., 1987; Spencer et al., 1995). Hence, the protective role of various plant extracts have been evaluated against Aluminiun induced hepatotoxicity( Shrivastava, 2013; Yakubu et al., 2016; Alqayim,2015; Dass and Ramoji, 2017).

In view of the reported hepatoprotective properties of Moringa oleifera leaves, the present study was carried out to evaluate the protective role of ethanol leaf extract of Moringa oleifera against Aluminium chloride induced damage to the liver of male albino wistar rats.

\subsection{MATERIALS AND METHODS}

\subsection{Chemicals and Reagents}

Aluminium chloride was obtained from Guangdong Guanghua Sci-Tech Company Limited, China. Reagent kits used for the determination of biochemical parameters were products of Randox Laboratories Ltd., England. All the other chemicals used in this study were of analytical grade (AR).

\subsection{Collection of Leaf Samples and Preparation of Extract}

Fresh leaves of Moringa oleifera were obtained from a local plantation in Uyo, Akwa Ibom State, Nigeria. They were identified and authenticated by the curator in the Pharmacognosy Herbarium, Faculty of Pharmacy, University of Uyo. The leaves were washed clear of dust particles and air dried at room temperature for two weeks. The dried leaves were ground into a powder using a kitchen blender. The powdered sample was extracted in $80 \%$ ethanol. The extract was filtered through Whatman No. 1 filter paper. The resulting extract was concentrated and evaporated to dryness using a Rotary Evaporator at $40^{\circ} \mathrm{C}$. The extract was further reconstituted in distilled water and preserved in a refrigerator maintained at $4^{\circ} \mathrm{C}$.

\subsection{Experimental Animals}

Eighteen (18) male albino Wistar rats were procured from the animal house facility of Faculty of Basic Medical Sciences, University of Uyo, Uyo, Nigeria.
They were housed in well ventilated wire-wooden cages and maintained under standard conditions (temperature, $28 \pm 3^{\circ} \mathrm{C}$; relative humidity, $67 \pm 3 \%$; 12 hours light/dark cycle). The animals were allowed unrestricted access to drinking water and rat chow (Livestock Feeds Plc, Lagos, Nigeria). The animals were cared for in accordance with the United States National Institute of Health Guidelines for the Care and Use of Laboratory Animals in Biomedical Research (NRC, 1985). Institutional approval for the study was obtained from the Postgraduate School, University of Uyo, Uyo.

The rats were allowed to acclimatize for a period of fourteen days after which they were randomly divided into three groups of six animals per group. Group 1 served as control and received $1.0 \mathrm{ml}$ of distilled water; Group 2 received $100 \mathrm{mg}$ of $\mathrm{AlCl}_{3}$ per $\mathrm{kg}$ body weight of rat; Group 3 was treated with 300 $\mathrm{mg}$ of the ethanol leaf extract of Moringa oleifera and $100 \mathrm{mg}$ of $\mathrm{AlCl}_{3}$ per $\mathrm{kg}$ body weight of rat. Administration of extract and $\mathrm{AlCl}_{3}$ was carried out by oral garage, once daily, between the hours of 8 and 10 am for a period of 28 days.

\subsection{Collection of Blood Samples}

At the end of the experimental period, the animals were allowed to fast for 12 hours and thereafter sacrificed under chloroform anaesthesia. Blood samples were collected by cardiac puncture using sterile needles and syringes. One portion of blood was transferred into EDTA sample bottles and used for the determination of haematological parameters. The second portion of blood was collected in sterile plain bottles and allowed to clot. Serum was separated from the clot by centrifugation at $3000 \mathrm{~g}$ for 5 mins using a bench top centrifuge (MSE minor, England). The serum samples were stored frozen $\left(-20^{\circ} \mathrm{C}\right)$ until required for analysis.

\subsection{Determination of Haematological Parameters}

The automated haematologic analyzer (Sysmex KX21) was used to analyze the haematological parameters at the Department of Haematology, University of Uyo Teaching Hospital, Uyo, Nigeria.

\subsection{Determination of Biochemical Parameters}

AST, ALT and ALP were analysed using reagent kits from Randox Laboratories, England. Estimation of total serum cholesterol was carried out using the cholesterol oxidase phenol aminosphenazone (CHOD-PAP) method whereas high density lipoprotein cholesterol was analysed by the polyethylene glycol cholesterol oxidase phenol aminophenazone (PEG-CHOD-PAP) method. Triacylglycerols (TGs) were determined using the glycerol phosphate oxidase, phenol aminophenozone (GPO-PAP) end point assay. LDL-cholesterol was obtained by calculation (Friedwald et al., 1972). 
Evaluation of the Protective Effect of Moringa oleifera Leaf Extract against Aluminium Induced Liver Damage in Male Albino Wistar Rats

Reagent kits for lipid analyses were obtained from Randox Laboratories, England.

\subsection{Histopathological Examination of Liver Samples}

A portion of the liver was removed, fixed in buffered formalin and embedded in paraffin wax. Tissue sections $(5 \mu \mathrm{m})$ were prepared and stained with Hematoxylin and Eosin (H\&E) for microscopic examination (Bancroft et al., 1996).

\subsection{Statistical Analysis}

Results were expressed as mean \pm standard deviation. The data obtained were analyzed by one-way ANOVA. Duncan's Multiple Range test (Duncan, 1955) was used to determine the significance of difference between means. Statistical significance was accepted at $\mathrm{P}<0.05$.

\subsection{RESULTS}

Table 1 shows the effect of ethanol leaf extract of Moringa oleifera on Aluminium chloride induced increase in the activities of AST, ALT and ALP in male rats. This table indicates that treatment with Aluminium chloride (Group 2) precipitated a significant increase $(p<0.05)$ in enzyme activities. Co-administration of ethanol leaf extract of Moringa oleifera with Aluminium chloride reversed enzyme activities towards normal values (Group 3).

The effect of ethanol leaf extract of Moringa oleifera on Aluminium chloride induced alterations in serum lipid profile of male rats is presented in Table 2 . Aluminium chloride induced a generalized significant increases $(p<0.05)$ in serum concentrations of total cholesterol (TC), triacylglycerol (TAG) and low density lipoprotein cholesterol (LDL-C), whereas there was a significant decrease $(p<0.05)$ in HDL-C. Administration of aluminium chloride with ethanol leaf extract of Moringa oleifera ameliorated the dyslipidemia caused by Aluminium chloride (Group $3)$.

Table 3 shows the effect of ethanol leaf extract of Moringa oleifera on Aluminium chloride induced changes in haematological indices of male rats. There was a significant decrease $(p<0.05)$ in $\mathrm{PCV}, \mathrm{Hb}$, $\mathrm{RBC}$, lymphocytes and platelets as a consequence of exposure to Aluminium chloride. The WBC and neutrophils increased significantly $(p<0.05)$. The $\mathrm{MCH}$ and $\mathrm{MCHC}$ were not affected. Ethanol leaf extract of Moringa oleifera moderated most of the haematological effects of Aluminium chloride.

The effects of Aluminium chloride and ethanol leaf extract of Moringa oleifera on the histology of the liver are shown in Figures I - III. The liver of control animals demonstrated normal histoarchitecture (Figure I). Administration of Aluminium chloride induced histopathological changes including inflammation, vacuolation and vascular degeneration (Figure II) which were reversed by the ethanol leaf extract of Moringa oleifera (Figure III).

\subsection{DISCUSSION}

Aluminium is extensively used in daily life and it is potentially toxic to man. The present study evaluated the protective effects of ethanol leaf extract of Moringa oleifera against the toxicity of Aluminium chloride on the liver of male rats by the measurement of some biochemical parameters, haematological indices and histopathological examination.

Toxic injury to the liver is associated with the release of some marker enzymes into circulation (Batzakis and Briere, 1979; Jaeschke et al., 2013). In the present study, hepatic damage was assessed by the assay of liver specific enzymes (AST, ALT and ALP). Administration of Aluminium chloride caused a significant increase $(\mathrm{P}<0.05)$ in the activity of these enzymes. This observation is in agreement with other reports which demonstrated that exposure to Aluminium chloride induced necrosis of the liver with elevation in the activities of liver specific enzymes (Abbdel-Wahab, 2012; Onyegeme-Okerenta and Anacletus, 2016; Yakubu et al., 2016). AST and ALT are amino transferase enzymes that are usually released into plasma as a consequence of hepatic damage (Naik, 2010). ALP is a membrane bound enzyme (Larkshmi et al., 1991). The increase in serum activity of ALP has been attributed to membrane damage consequent upon Aluminium chloride intoxication (Nehru and Anand, 2005; Abbdel-Wahab, 2012).

Administration of ethanol leaf extract of Moringa oleifera restored the activities of AST, ALT and ALP towards normal. This is an indication of improved liver function and protection against the hepatotoxicity of Aluminium chloride. This observation is in consonance with other studies which reported that the leaf extract of Moringa oleifera significantly reduced the elevated activities of liver enzymes induced by toxicants (Saalu et al., 2012; Karthivashan et al., 2013; Shiekh et al, 2014; Toppo et al., 2015). The hepatoprotective effects of Moringa oleifera leaves have been observed to follow the antioxidant mediated mechanism provided by various bioactive compounds (Fakurazi et al., 2012; El-bakry et al., 2016).

The liver is pivotal in the metabolism of lipids and lipoproteins (Havel and Kane, 2001). Thus, hepatic damage may induce alterations in the serum concentrations of cholesterol, low density lipoprotein cholesterol, high density lipoprotein cholesterol and triacylglycerol (Halim et al., 1997).The present study has demonstrated that Aluminium chloride 
precipitates a significant upsurge in total cholesterol, low density lipoprotein cholesterol, triacylglycerol, but significantly lowered the serum concentration of high density lipoprotein cholesterol. This pattern of dyslipidemia has been recognized as a risk factor for the development of atherosclerosis and other cardiovascular diseases (Yakubu et al., 2008; Divi et al., 2012; Singh et al., 2012). The results obtained in this study are in line with those of other authors (Nampoothiri et al., 2015; Dass and Ramoji, 2017).

LDL-cholesterol is the primary carrier of cholesterol from the liver to extrahepatic tissues for utilization (Oparinde et al., 2014). Elevated concentrations of cholesterol and LDL-cholesterol following the administration of $\mathrm{AlCl}_{3}$ as observed in this study have been attributed to two factors: (i) Enhanced $\beta$ oxidation of fatty acids resulting in high levels of acetylCoA which serve as key substrate in the biosynthesis of cholesterol (Yakubu and Afolayan, 2009; Naik, 2010). (ii) Accumulation of $\mathrm{AlCl}_{3}$ in the liver resulting in loss of membrane integrity which has been observed to be associated with hyperlipidemia and/or hypercholesterolemia in human and animal studies (Sarin et al., 1997; Yuosef, 2004; Newairy et al., 2009).

HDL-cholesterol (the good cholesterol) mediates the reverse transport of cholesterol from extrahepatic tissues to the liver for degradation and excretion as bile acids (Kwiterovich, 2000; Das, 2003). HDL-C is reported to possess anti-atherogenic properties. There is an inverse relationship between HDL-C and coronary heart disease (Yakubu and Afolayan, 2009). Administration of $\mathrm{AlCl}_{3}$ was observed to decrease serum concentrations of HDL-cholesterol which is in agreement with the report of other authors (John et al, 2015; Ugbaja et al., 2015) indicating increased risk of atherosclerosis.

Triacylglycerols represent the major storage forms of lipids. The observed increase in serum concentration of TAGs in response to $\mathrm{AlCl}_{3}$ has been attributed to its ability to enhance lipolysis (Yakubu and Afolayan, 2009).

Ethanol leaf extract of Moringa oleifera ameliorated the dyslipidemia precipitated by Aluminium chloride. The leaves of Moringa oleifera are reported to be rich in proteins, vitamins, carotenoids, vitamins and polyphenols such as kaempferol, rhamnetin, quercitin, chlorogenic acid rutin and apigenin (Amaglo et al, 2010; Karthivashan et al., 2013). The hypolipidemic effect of Moringa leaves has been attributed to its antioxidant activity and ability to preserve cellular membrane integrity from Aluminium induced oxidative damage. El-bakry et al (2016) observed that polyphenols present in Moringa oleifera act as free radical scavengers and are mainly responsible for antioxidative activity of the leaf extract. Other mechanisms which have been proposed to account for the hypolipidemic activity of polyphenols include: (i) increase in cholesterol elimination via bile acids (Doucet et al, 1987) (ii) up regulation of LDL receptor expression, (iii) inhibition of hepatic lipid synthesis and lipoprotein secretion (Bhandari et al., 2011). Lee et al (2003) reported that flavonoids inhibit cholesterol biosynthesis and esterification by reducing the activity of HMGCoA reductase, a key enzyme in this pathway. The leaf extract of Moringa oleifera has been reported to be rich in flavonoids. (Manguro and Lemmen, 2007).

The evaluation of haematological parameters is an important biomarker for the determination of the haematoxic potential of xenobiotics (Kalaiselvi et al., 2015). The observed decrease in $\mathrm{Hb}, \mathrm{PCV}$ and RBC indicate the potential to develop anaemia following exposure to Aluminium chloride. This result is consistent with the report of other authors (Osman et al., 2012; Anacletus and Onyegeme-Okerenta, 2016; Selvi and Alagesan, 2017; Yakubu et al., 2017). Mechanisms that have been advanced to explain the aluminium induced aneamia include lysis of the erythrocytes (Selvi and Alagesan, 2017) and the inhibition of haem synthesis either by repression of enzyme activity or interference with the incorporation of iron into haem (Kaiser and Schwartz, 1985; Han et al., 2000).

The present study also demonstrated that Aluminium chloride did not induce any significant alterations in the values of $\mathrm{MCH}$ and MCHC. This is in line with the findings of other authors (Kalaiselvi et al., 2015; Selvi and Alagesan, 2017).

Administration of ethanol leaf extract of Moringa oleifera moderated the negative impact of Aluminium chloride on PCV, $\mathrm{Hb}$ and RBC. This may be explained by the fact that the leaf extract of Moringa oleifera contains a profile of nutrients such as protein, amino acids, trace elements and various phenolics (Amaglo et al., 2010). Ebenebe et al. (2012) had reported that the supplementation of broiler chicks with Moringa oleifera leaves resulted in a significant increase in $\mathrm{PCV}, \mathrm{Hb}$ and $\mathrm{RBC}$. In ethnomedicine, the consumption of Moringa leaves is recommended for the treatment of anaemia (Subadra et al., 1997).

The WBCs and their differentials are indicators of the ability of an organism to fight infections (Dacie and Lewis, 2006). The significant increase in WBCs in response to Aluminium chloride can be considered to be a normal immune response to toxic insult (Nussey et al., 2002; Igwe et al., 2011). It is noteworthy that an increase in the total number of WBCs does not 
necessarily translate into a generalised increase in all types of leukocytes (Yakubu and Afolayan, 2009).

The neutrophils are the principal phagocytic and microbicidal responders in the immune system (Willey et al., 2013). Increase in neutrophil is usually considered as an index of tissue damage or the entry of foreign bodies into the blood stream (Sakthivel, 1988). A significant increase in neutrophil count as a consequence of exposure of African cat fish to Aluminium has also been reported by Selvi and Alagesan ( 2017).

The lymphocytes are the primary cells involved in specific immune reactions to foreign matter (Willey et al, 2013). In the present study, treatment with Aluminium chloride induced a significant decrease in lymphocyte count. Aluminium induced lymphopenia has been attributed to the capacity of this element to induce oxidative stress and exert genotoxic damage to the lymphocytes (Garcia-Medina et al, 2010).

The platelets are blood components involved in coagulation. A decrease in platelet count as observed in this study implies an inhibitory effect on thrombopoietin secretion (Malomo et al, 2002). A similar decrease in platelet count as a consequence of exposure to aluminium has been reported by Anacletus and Onyegeme-Okerenta, (2016).

Administration of ethanol leaf extract of Moringa oleifera was observed to restore to normal most of the immunological alterations induced by Aluminium chloride. The immunomodulatory effects of the leaf extract of Moringa oleifera is due to the wide range of macronutrients, micronutrient and phytochemicals found in this plant (Nfambi et al., 2015).

Histopathological evaluation plays an important role in the assessment of the adverse effects of xenobiotics (Reddy and Rawat, 2013). The histopathological results of the present study confirm the hepatotoxic effects of Aluminium chloride and recovery consequent upon treatment with ethanol leaf extract of Moringa oleifera. Similar histopathological results have been obtained with the use of other bioactive substances against aluminium hepatotoxicity (Mahmoud and Elsoadaa, 2013; Shrivastava, 2013).

\subsection{CONCLUSION}

The present study has provided supportive evidence that the oral administration of Aluminium chloride in male rats at a dose of $100 \mathrm{mg} / \mathrm{kg}$ body weight daily for a period of 28 days induces hepatic dysfunction as evidenced in significant alterations in some biochemical, haematological and histological parameters. The use of ethanol leaf extract of Moringa oleifera in combination with Aluminium chloride was observed to attenuate some of the harmful effects of this element. Therefore, supplementation with Moringa oleifera leaves may prove useful as protective therapy against the hepatotoxic effects of Aluminium chloride.

\section{REFERENCES}

1. Abbasali, K.M., Zhila T. and Farshad, N. (2005) Developmental toxicity of aluminium from high doses of $\mathrm{AlCl}_{3}$ in mice. The J. of Applied Research, 5, 575-579.

2. Abbdel-Wahab, W.M. (2012). $\mathrm{AlCl}_{3}$-induced toxicity and oxidative stress in liver of male rats: protection by melatonin. Life Science Journal, 9(4): 1173-1181.

3. Alqayim, M.A.J. (2015). Propolis cardioprotective role from the impact of aluminium chloride in female rabbits. Bas. J. Vet. Res., 14(2):136-149.

4. Amaglo, N.K., Bennett, R.N., Lo-Curto, R.B., Rosa, E.A.S., Lo-Turco, V., Giuffrid, A., Lo-Curto, A, Crea, F. and Timpo, G.M. (2010). Profiling selected phytochemicals and nutrients in different tissues of the multipurpose tree Moringa oleifera Lam. grown in Ghana. Food Chemistry, 122, 1047-1054.

5. Anacletus, F. C. and Onyegeme-Okerenta, B. M. (2016) Induction of haematological and lipid profile changes by aluminium induced toxicity and ameliorative effects of selected antioxidants on Wistar rats. Health Science Research, 3(3):30-34.

6. Anwar, F. and Bhanger, M.I. (2003). Analytical characterization of Moringa oleifera seed oil grown in temperate regions of Pakistan. J. Agric. Food Chem, 51, 6558-6563.

7. Anwar, F., Latif S. Ashraf, M. and Gulani, A. H. (2007) Moringa oleifera: A food plant with multiple medicinal uses. Phytotherapy Research, 21, 17-25.

8. Bancroft, D., Steves, A. and Turner, R. (1996). Theory and Practice of Histopathological Techniques. $4^{\text {th }}$ ed. Churchill Livingstone, London, pp. 47-67.

9. Batzakis, K.G. and Briere, R.O. (1979). Interpretative Enzymology. Thomas Nelson. Springfield. Illinois, pp. $225-$ 242.

10. Bhandari, U., Kumar, V., Khanna, N. and Panda, B.P. (2011). The effect of high fat diet induced obesity on cardiovascular toxicity in wistar albino rats. Hum. Exp. Toxicol. 30(9): 1313-1321.

11. Bosch, C.H. (2004). Moringa oleifera Lam. Plant Resources of Tropical Africa. PROTA. Wageningen, Netherlands, pp. 112

12. Buraimoh, A.A . (2011). Hepatoprotective effect of ethanol leaf extract of Moringa oleifera on the histology of paracetamol induced liver damage in rats. Intl. J. Anim. Vet. Adv., 3, 10-13.

13. Dacie, J.V. and Lewis, S.M. (2006). Investigation of haematological disorders. Practical Haematology, Churchill Livingtone, Edinburgh, UK. pp. 177-180.

14. Dolara, P. (2014). Occurrence, exposure, effects, recommended intake and possible dietary use of selected trace compounds (aluminium, bismuth, cobalt, gold, lithium, nickel, silver). International Journal of Pharmaceutical and Chemical Sciences, 2(1): 415-423.

15. Das, D.K. (2003). Cardioprotection with high density lipoproteins. Fact or Fiction? Circ. Res. 93, 258-260.

16. Dass, A.P. and Ramoji, P.C (2017). The effect of aqueous ginger extract on aluminium chloride $\left(\mathrm{AlCl}_{3}\right)$ induced alteration in lipid profile of male Wister rats. International Journal of Basic and Clinical Pharmacology, 6, 1-4.

17. Divi, S.M., Bellamkonda, R. and Dasireddy, S.K. (2012). Evaluation of antidiabetic and antihyperlipidemic potential of aqueous extract of Moringa oleifera in fructose fed insulin resistant and STZ induced diabetic Wistar Rats: A comparative study. Asian Journal of Pharmaceutical and Clinical Research, 5, 67-72.

18. Doucet, C., Flament, C., Sautier, C. and Lemonnier, D. (1987). Effect of an hypercholesterolemic diet on the level of 
several serum lipids and apolipoproteins in nine rat strains. Reprod. Nutr. Dev., 27, 897-906.

19. Duncan, DB (1955). Multiple Range and Multiple F tests. Biometrics, 11, 1-42.

20. Ebenebe, C. I., Umegechi, C. O. and Nweze B. O. (2012). Comparison of haematological parameters and weight changes in broiler chicks fed different levels of Moringa oleifera diet. Int. J. of Agric. and Biosciences, 1, 23-25.

21. El-bakry, K., Toson, E., Serag, M. and Aboser.M. (2016). Hepaprotective effect of Moringa oleifera leaves extract against carbon tetrachloride induced liver damage in rats. World Journal of Pharmacy and Pharmaceutical Sciences, 5(5): 76-89

22. Ekong, M.B., Ekpo, M.M., Akpanyung, E.O. and Nwaokonko, D.U. (2017). Neutroprotective effect of Moringa oleifera leaf extract on aluminium induced temporal cortical degeneration. Metabolic Brain Disease, 32(5): 14371447

23. Exley, C. (1998). Does antiperspirant use increase the risk of aluminium-related disease including Alzheimer's disease? Molecular Medicine Today, 4, 107-116.

24. Fakurazi, S., Sharifudin, S.A. and Arulselvan, P. (2012). Moringa oleifera hydroethanolic extracts effectively alleviate acetaminophen-induced hepatotoxicity in experimental rats through their antioxidant nature. Molecules, 17, 8334-8350.

25. Friedewald, W.T., Levy, R.I. and Fredrickson, D.S (1972). Estimation of the concentration of low density lipoprotein cholesterol in plasma without the use of preparative ultracentrifuge. ClinicalChemistry, 18, 499-502.

26. Galle P., Guidicelli C.P.and Nebout T. (1987). Ultrastructural localization of aluminium in hepaotcytes of haemodialysed patients. Ann . Pathol, 7, 163-170.

27. Garcia-Medina, S., Razo-Estrada, A.C., Gomez-Olivan, L.M., Amaya-Chavez, A., Bujaidar, M.E. and GalarMartinez, M. (2010). Aluminium induced oxidative stress in lymphocytes of common carp (Cyprinus carpi). Fish. Physiol. Biochem., 36, 875-882.

28. Gauthier E., Fortier I., Courchesne F, Pepin P., Mortimer J. and Gauvreau D. (2000). Aluminium forms in drinking water and risk of Alzheimer's disease. Environmental Research, 84 (3): 234-246

29. Greger, J.L. (1992). Dietary and other sources of aluminium intake. In: Aluminium in Biology and Medicine. Ciba Foundation Symposium, 169, 26-29.

30. Halim, A.B., El-Ahmady, O., Hassab-Allah, S., AbbdelGalil, F., Hafz, Y. and Darwish, A. (1997). Biochemical effect of antioxidants on lipids and liver function in experimentally induced liver damage. Ann. Clin. Biochem., 34, 656-653.

31. Havel, R.J. and Kane, J.P. (2001). Structure and Metabolism of Plasma Lipoproteins. In: The metabolic and molecular basis of inherited diseases. Scriver, C.R., Beaudet, A.L., Sly, W.S., Valle, M.B., Childs, B., Kinzler, K.W. and Vogelstein, B. eds. McGraw Hill, New York, pp. 2705-2716.

32. Han, J., Han, J. and Dunn, M.A. (2000). Effect of dietary aluminium on tissue non-heme iron and ferritin levels in the chick. Toxicology, 142(2):97-109.

33. Hanchez-Leroy F. (2013). Aluminium in health and food: a gradual global approach. European Review of History, 20(2): 217-236.

34. Hsu, R., Midcap, S. and Lucinenne de Witte, A.L. (2006). Moringa oleifera, medical and socio-economic uses. Intl. J. of Econ. Botany, 1, 1-25.

35. Igwe, C.U., Onwuliri, V.A., Osuagwu, C.G., Onyeze, G.O.C. and Ojiako, O.A. (2011). Biochemical and haematological studies on ethanol leaf extract of Spondias mombin Linn. Biochem. Anal. Biochem, 1 (1): 1-5.

36. Jaeschke, H., Williams, C.D., McGill, M.R., Xie, Y. and Ramachandran, A. (2013). Models of drug induced liver injury for evaluation of phytotherapeutics and other natural products. Food Chem. Toxicol., 55, 279-289.

37. John, J., Nampoothiri, M., Kumar, N., Mudgal, J., Nampurath, G.K. and Chanmallamudi, M.R. (2015). Sesamol, a lipid lowering agent ameliorates aluminium chloride induced behavioral and biochemical alterations in rats. Pharmacog. Mag., 11(42): 327-336.

38. Kaechny W., Hegg A. and Alfrey A. (1997). Gastrointestinal absorption of aluminium from aluminium containing antacids. New England Journal of Medicine, 296, 1389-1390.

39. Kaiser, L. and Schwartz, K.A. (1985). Aluminium-induced anemia. Am. J. Kidney Dis., 6 (5): 348-352.

40. Kalaiselvi, A. Aadhinaath, R.G. and Ramalingam, V. (2015) Effect of aluminium chloride and protective effect of ginger extract on hematological profiles of male wistar rats. International Journal of Pharmaceutical and Phytopharmacological Research, 4 (4): 218-222.

41. Kwiterovich Jr, P.O. (2000). The metabolic pathways of high density lipoprotein, low density lipoprotein and triglycerides. A current review. American Journal of Cardiology, 86, 5-10.

42. Karthivashan, G., Tangestani, F.M., Arulselvan, P., Abas, F. and Fakurazi, S. (2013). Identification of bioactive candidate compounds responsible for oxidative damage from hydroethanolic extract of Moringa oleifera leaves. Journal of Food Science, 78(9): 1368-1375.

43. Klein, G. L., Berquist, W. E., Ament, M. E., Coburn, J. W., Miller, N. L. and Alfrey, A. C. (1984). Hepatic aluminium accumulation in children on total parenteral nutrition, Gastroenterology and Nutrition, 35(5): 740-743.

44. Kumar, P.S., Mishra, D., Ghosh, G. and Panda, G.S (2010) Medicinal uses and pharmacological properties of Moringa oleifera. Inter. J. Phytomed., 2, 210-216.

45. Larkshmi, R., Kundu, R., Thomas, E. and Mansuri, A. P. (1991). Mercuric Chloride induced inhibition of acid and alkaline phosphatase activity in the kidney of mudskipper, Boleopthalnius dentatus. Acta hydrochim.Hydrobiol., 3, 341344.

46. Lee, M.K., Moon, S.S., Lee, S.E., Bok, S.H., Jeong, T.S., Park, Y.B. and Choi, M.S (2003). Naringenin 7-0-cetyl ether as inhibitor of HMG-CoA Reductase and Modulator of Plasma and Hepatic lipids in High-cholesterol Fed Rats. Bioorg Med. Chem., 11, 393.

47. Mahmoud, M.E. and Elsoadaa, S.S. (2013). Bioactive effect of ascorbic acid, biopropolis and royal jelly against aluminium toxicity in rats. Journal of Natural Sciences Research, 3 (1): 102-111.

48. Malomo, S.O., Adebajo, J.O. and Olorunniji, F.J. (2002) Modulatory effect of vitamin E on some haematological parameters in dihydroartemisinin-treated rats. Trop. J. Health Sci., 9, 15-20.

49. Manguro, L.O. and Lemmen, P. (2007). Phenolics of Moringa oleifera leaves. Nat. Prod. Res. 21, 56-68.

50. Naik, P. (2010). Biochemistry ( $3^{\text {rd }}$ edn.). Jaypee Publishers, pp 564-565.

51. Nampoothiri, M., John, J., Kumar, N., Mudgal, J. Nampurath, G.K. and Chamallamudi, M.R. (2015) Modulatory role of simvastatin against aluminium chloride induced behavioural and biochemical changes in rats. Behavioural Neurology, Article ID 210169, 9 pages.

52. National Research Council (1985). Guide for the care and use of laboratory animals. Publication of the National Institute of Health, Bethesda, MD.

53. Nehru, B. and Anand, P. (2005). Oxidative damage following chronic aluminium exposure in adult and pup rat brains. Journal of Trace Elements in Medicine \& Biology, 19, 203 208.

54. Newairy, A.S., Salama, A.F., Hussein, H.M. and Yousef, M.I. (2009). Propolin alleviates aluminium induced lipid peroxidation and biochemical parameters in male rats. Food and Chemical Toxicology, 47(6): 1093-1098.

55. Nfambi, J., Bbosa, G.S., Sembajwe, L.F., Gakunga, J. and Kasolo, J.N. (2015). Immunomodulatory activity of methanolic leaf extract of Moringa oleifera in wistar albino rats. J. Basic Clin. Physiol. Pharmacol., 26 (6): 603-611.

56. Nussey, G., Van Vuren, J.H.J. and Du Preez, H.H. (2002). The effect of copper and zinc at neutral and acidic $\mathrm{pH}$ on the general haematology and osmoregulation of Oreochromis mossambicus. African Journal of Aquatic Science, 27 (1): 6184. 
57. Odee, D. (1998). Forest biotechnology research in dry lands of Kenya. J. Dryland Biodivers., 2,7-8.

58. Onyegeme-Okerenta, B.M. and Anacletus, F.C. (2016). Hepatoprotective and ameliorative effects of selected antioxidants on aluminium induced toxicity in on Wistar rats. European Journal of Advanced Research in Biological and Life Sciences, 4(2): 24-34.

59. Oparinde, D.P., Atiba, A.S., Ajose, O.A., Eludoyin, A.A. and Adesiyan, A.A. (2014). Effect of Moringa oleifera leaf extract on serum lipids and glycaemic control in alloxan induced diabetic albino rats. International Journal of Biomedical and Advance Research, 05(10): 519-522.

60. Osman, H.M., Shayoub, M.E., Babiker, E.M., Osman, B. and Elhassan, A.M. (2012). Effect of ethanolic leaf extract of Moringa oleifera on aluminium induced anemia in white albino rats. Jordan Journal of Biological Sciences, 5(4): 255260.

61. Parrotta, J.A. (2005). Moringa oleifera Lam. In: Encyclopedia of Woody Plants. USDA Forest Service, International Institute of Tropical Forestry. Ecomed Verlag, Germany, pp. 1-8.

62. Peixoto, J.R.O., Silva, G.C., Costa, R.A., de Sousa Fontelle, J.R., Veira, G.H., Filho, A.A. and dos Fernandes Vieira, R.H. (2011). In vitro antibacterial effect of aqueous and ethanolic Moringa leaf extract. Asian Pacific Journal of Tropical Medicine, 4(3): 201-204.

63. Reddy, P.B. and Rawat, S.S. (2013).Assessment of aquatic pollution using histopathology in fish as a protocol. International Research Journal of Environmental Sciences, 2 (8): 79-82.

64. Saalu, L.C., Ogunlade, B., Ajayi, G.O., Oyewopo, A.O., Akunna, G.G. and Ogunmodede, O.S. (2012). The hepatoprotective potentials of Moringa oleifera leaf extract on alcohol induced hepato-toxicity in Wistar rat. American Journal of Biotechnology and Molecular Sciences, 2(1): 6 14

65. Sakthivel, M. (1988). Effects of varying dietary protein level on blood parameters of Cyprinus carpio. Proc. Ind. Acad. Sci. Anim. Sci., 97 (4): 363-366.

66. Sarin, S., Gupta, V. and Gull, K.D. (1997). Alterations in lipid composition and neuronal injury in primates following chronic aluminium exposure. Biol. Trace Elem. Res., 59,133143.

67. Selvi, A.T. and Alagesan, P. (2017). Toxic effect of aluminium on haematological and immunological profile of African cat fish, Clarias gariepinus. Middle East Journal of Scientific Research, 25 (4): 678-683.

68. Sheikh, A., Yeasmin, F., Agarwal, S., Rahman, M., Islam, K., Hossain, E., Hossain, S., Karim, M. R., Nikkon, F., Saud, Z A., and Hossain, K. (2014). Protective effects of Moringa oleifera Lam. Leaves against arsenic-induced toxicity in mice. Asian Pac. J. Trop. Biomed., 4(1): 353-358.

69. Shrivastava, S. (2013). Amelioration of aluminium induced toxicity by Allium sativum. Scientific Research and Assays, 8(4): 168-177.

70. Singh, R., Singh, S., Singh, S.P., Jain, I.P. and Singh, S. (2012). Study of alteration in serum lipids by cardio selective beta blockers in albino rats. Asian Journal of Pharmacy and Life Science, 2, 166-173.
71. Sorenson, J.R., Campbell, I.R., Tepper, L.B. and Lingg, R.D. (1974). Aluminium in the environment and human health Environmental Health Perspective, 8, 3-95.

72. Spencer, A.J., Wood A.J., Saunders, H.C., Freeman, M. S and Lote C.J. (1995). Aluminium deposition in liver and kidney following acute intravenous administration of aluminium chloride or citrate in conscious rats. Hum. Exper. Toxicol, 14, 787-79.

73. Subadra, S., Monica, J. and Dhabhai, D. (1997). Retention and storage stability of beta carotene in dehydrated drumstick leaves. Int. J. of Fd. Science and Nutrition, 48, 373-379.

74. Thilza, B., Sanni, S., Zakari A. I., Sanni, F. S., Muhammed, T. and Musa, B.J. (2010). In vitro antimicrobial activity of water extract of Moringa oleifera leaf stalk on bacteria normally implicated in eye diseases. Academia Arena, 2(6): $80-82$

75. Toppo, R., Roy, B.K., Gora, R.H., Baxla, S.L. and Kumar, P. (2015).Hepatoprotective activity of Moringa oleifera against cadmium toxicity in rats. Veterinary World, 8(4): 537-540.

76. Ugbaja, R.N., Olaniyan, T.O., Afolabi, O.K., Dosumu, O.A. Akinloye, D.I., Mufuatu, A.O. and Nwa-John, O.P (2015) Vitamins $\mathrm{C}$ and $\mathrm{E}$ attenuate lipid dystrophy in tissues of rats administered aluminium. Biokemistri, 27, 98-105.

77. WHO (2010). Aluminium in drinking water. Geneva Switzerland, p. 1.

78. WHO/FAO.(1989). Aluminium. In: Evaluation of certain food additives and contaminants. $33^{\text {rd }}$ Report of the joint FAO/WHO expert committee on food additives WHO Technical Report Series, 776, 26.

79. Willey, J., Sheerwood, L. and Wodeverton, C. (2013). Prescotts Microbiology $9^{\text {th }}$ ed. McGraw Hill Education.

80. Yakubu, M. T., Akanji, M. A., and Oladiji, A. T. (2008) Alterations in serum lipid profile of male rats on oral administration of aqueous extract of Fadogia agrestis stem. Res. J. Med. Plants, 2, 66.

81. Yakubu, M.T. and Afoloyan, A.J. (2009). Effect of aqueous extract of Bulbine natalensis (Baker) stem on haematelogical and serum lipid profile of male Wistar Rats. Indian J. of Experimental Biology, 47, 283-288.

82. Yakubu, O.E., Nwodo, O.F. C., Imo, C., Abdulrahaman, M. and Uyeh, L. B. (2016). Effects of Vitex doniana leaf extract on aluminium induced toxicity in male albino wistar rats. Journal of Applied Biology and Biotechnology, 4(5): 037-040

83. Yakubu, O.E., Nwodo, F.C., Imo, C. and Ogwoni, H.A (2017). Spermatogenic and haematological effects of aqueous and ethanolic extracts of Hymenocardiaacida stem bark on aluminium induced toxicity in male wistar rats. Insights in Biomedicine, 2 (1): 1-5.

84. Yokel, R.A. (2000). The toxicology of aluminium in the brain. A review. Neurotoxicology, 21(5):813-828.

85. Yuosef, M.I. (2004). Aluminium induced changes in haemato-biochemical parameters, lipid peroxidation and enzyme activities of male rabbits: protective role of ascorbic acid. Toxicology, 199, 47-57.

86. Zhang, K. and Zhou, Q. (2005). Toxic effects of aluminium based coagulants on Brassica chimensis and Raphanus sativus growing in acid and neutral conditions. Environmental Toxicology, 20(2): 179-187. 
Evaluation of the Protective Effect of Moringa oleifera Leaf Extract against Aluminium Induced Liver Damage in Male Albino Wistar Rats

Table 1: Effect of ethanol leaf extract of Moringa oleifera on aluminium chloride induced changes in the activities of some serum enzymes in male rats.

\begin{tabular}{llll}
\hline Group & AST (U/L) & ALT (U/L) & ALP(U/L) \\
\hline 1 & $13.03 \pm 0.25^{\mathrm{a}}$ & $18.80 \pm 0.55^{\mathrm{a}}$ & $58.01 \pm 0.80^{\mathrm{a}}$ \\
2 & $37.11 \pm 0.37^{\mathrm{b}}$ & $30.00 \pm 0.46^{\mathrm{b}}$ & $97.00 \pm 0.44^{\mathrm{b}}$ \\
3 & $14.87 \pm 0.60^{\mathrm{a}}$ & $20.12 \pm 0.57^{\mathrm{a}}$ & $60.36 \pm 0.52^{\mathrm{a}}$ \\
\hline
\end{tabular}

Values represent mean \pm SD

a-b Mean values within each column represented by the same alphabet are not significantly different $(P>0.05)$ by the Duncan's multiple range test.

Table 2: Effect of ethanol leaf extract of Moringa oleifera on aluminium chloride induced alterations in the lipid profile of male rats.

\begin{tabular}{lllll}
\hline Group & TC $(\mathrm{mg} / \mathrm{L})$ & TAG $(\mathrm{mg} / \mathrm{L})$ & HDLC(mg/L) & LDLC(mg/L) \\
\hline 1 & $67.14 \pm 0.90^{\mathrm{a}}$ & $19.80 \pm 0.36^{\mathrm{a}}$ & $29.16 \pm 0.54^{\mathrm{a}}$ & $39.42 \pm 1.26^{\mathrm{a}}$ \\
2 & $86.76 \pm 2.34^{\mathrm{b}}$ & $27.18 \pm 0.54^{\mathrm{b}}$ & $21.42 \pm 0.54^{\mathrm{b}}$ & $45.18 \pm 1.44^{\mathrm{b}}$ \\
3 & $72.54 \pm 5.40^{\mathrm{a}}$ & $24.84 \pm 0.36^{\mathrm{c}}$ & $28.64 \pm 0.72^{\mathrm{a}}$ & $41.48 \pm 1.26^{\mathrm{c}}$ \\
\hline
\end{tabular}

*Values represent mean $\pm \mathrm{SD}$.

${ }^{\mathrm{a}-\mathrm{c}}$ Mean values within each column represented by the same alphabet are not significantly different $(\mathrm{P}>0.05)$ by the Duncan's multiple range test.

Table 3: Effect of ethanol leaf extract of Moringa oleifera on aluminium chloride induced changes in some haematological parameters in male rats.

\begin{tabular}{llll}
\hline Parameter & Group 1 & Group 2 & Group 3 \\
\hline PCV $(\%)$ & $48.72 \pm 2.42^{\mathrm{a}}$ & $43.18 \pm 4.77^{\mathrm{b}}$ & $44.07 \pm 2.68^{\mathrm{b}}$ \\
$\mathrm{Hb}(\mathrm{g} / \mathrm{dl})$ & $13.26 \pm 0.23^{\mathrm{a}}$ & $8.97 \pm 0.56^{\mathrm{b}}$ & $10.92 \pm 0.42^{\mathrm{c}}$ \\
$\mathrm{RBC}\left(\mathrm{x} 10^{6} / \mu \mathrm{L}\right)$ & $7.85 \pm 0.21^{\mathrm{a}}$ & $4.82 \pm 0.37^{\mathrm{b}}$ & $7.11 \pm 0.46^{\mathrm{a}}$ \\
$\mathrm{MCH}(\mathrm{pg})$ & $17.43 \pm 0.30^{\mathrm{a}}$ & $16.90 \pm 0.30^{\mathrm{a}}$ & $17.22 \pm 0.21^{\mathrm{a}}$ \\
$\mathrm{MCHC}(\mathrm{g} / \mathrm{dl})$ & $30.37 \pm 0.31^{\mathrm{a}}$ & $28.75 \pm 0.44^{\mathrm{a}}$ & $28.88 \pm 0.49^{\mathrm{a}}$ \\
WBC $\left(10^{3} / \mu \mathrm{L}\right)$ & $6.30 \pm 0.06^{\mathrm{a}}$ & $9.48 \pm 0.05^{\mathrm{b}}$ & $7.00 \pm 0.08^{\mathrm{a}}$ \\
Platelets $\left(\mathrm{x} 10^{5} / \mu \mathrm{L}\right)$ & $788.33 \pm 1.28^{\mathrm{a}}$ & $737.33 \pm 0.61^{\mathrm{b}}$ & $639 \pm 0.68^{\mathrm{b}}$ \\
Lymphocytes $(\%)$ & $78.47 \pm 0.69^{\mathrm{a}}$ & $71.18 \pm 0.65^{\mathrm{b}}$ & $76.90 \pm 0.68^{\mathrm{a}}$ \\
Neutrophils $(\%)$ & $15.92 \pm 0.62^{\mathrm{a}}$ & $24.00 \pm 0.25^{\mathrm{b}}$ & $26.45 \pm 0.35^{\mathrm{a}}$ \\
\hline
\end{tabular}

*Values represent mean \pm SD

${ }^{\mathrm{a}-\mathrm{c}}$ Mean values within each row represented by the same alphabet are not significantly different $(\mathrm{P}>0.05)$ by the

Duncan's multiple range test. 
Evaluation of the Protective Effect of Moringa oleifera Leaf Extract against Aluminium Induced Liver Damage in Male Albino Wistar Rats
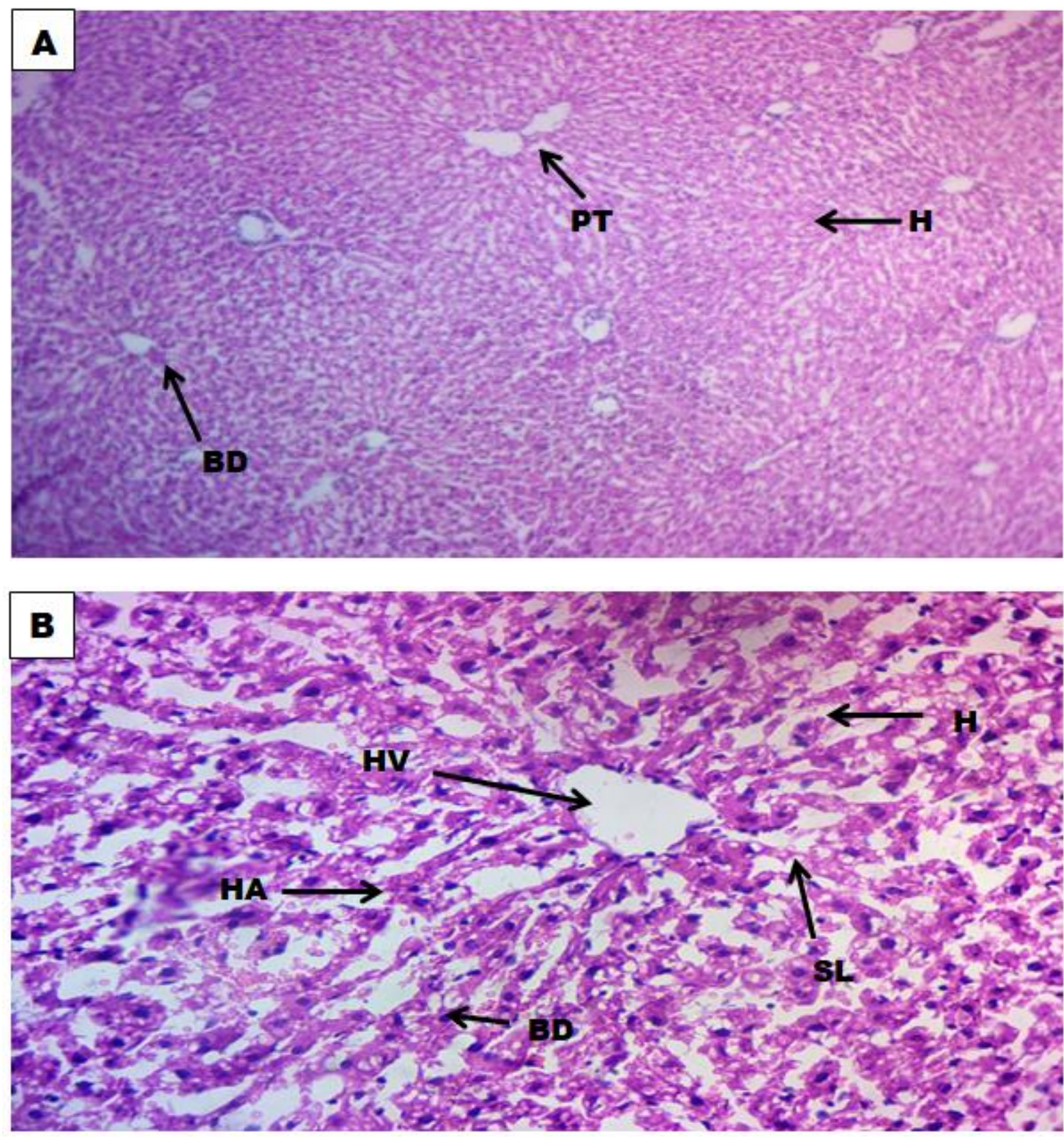

Figure I: Photomicrographs of liver of male albino Wistar rats without treatment (control); A (x100) and B (x400) reveal normal cellular profile of portal triad, bile duct, hepatic artery, hepatic vein, hepatocytes and nucleus within normal cellular architecture.

Key: Portal triade (PT), Bile duct (BD), Hepatic artery (HA), Hepatic vein (HV) Hepatocytes (H), Sinusoidal lining (SL). 

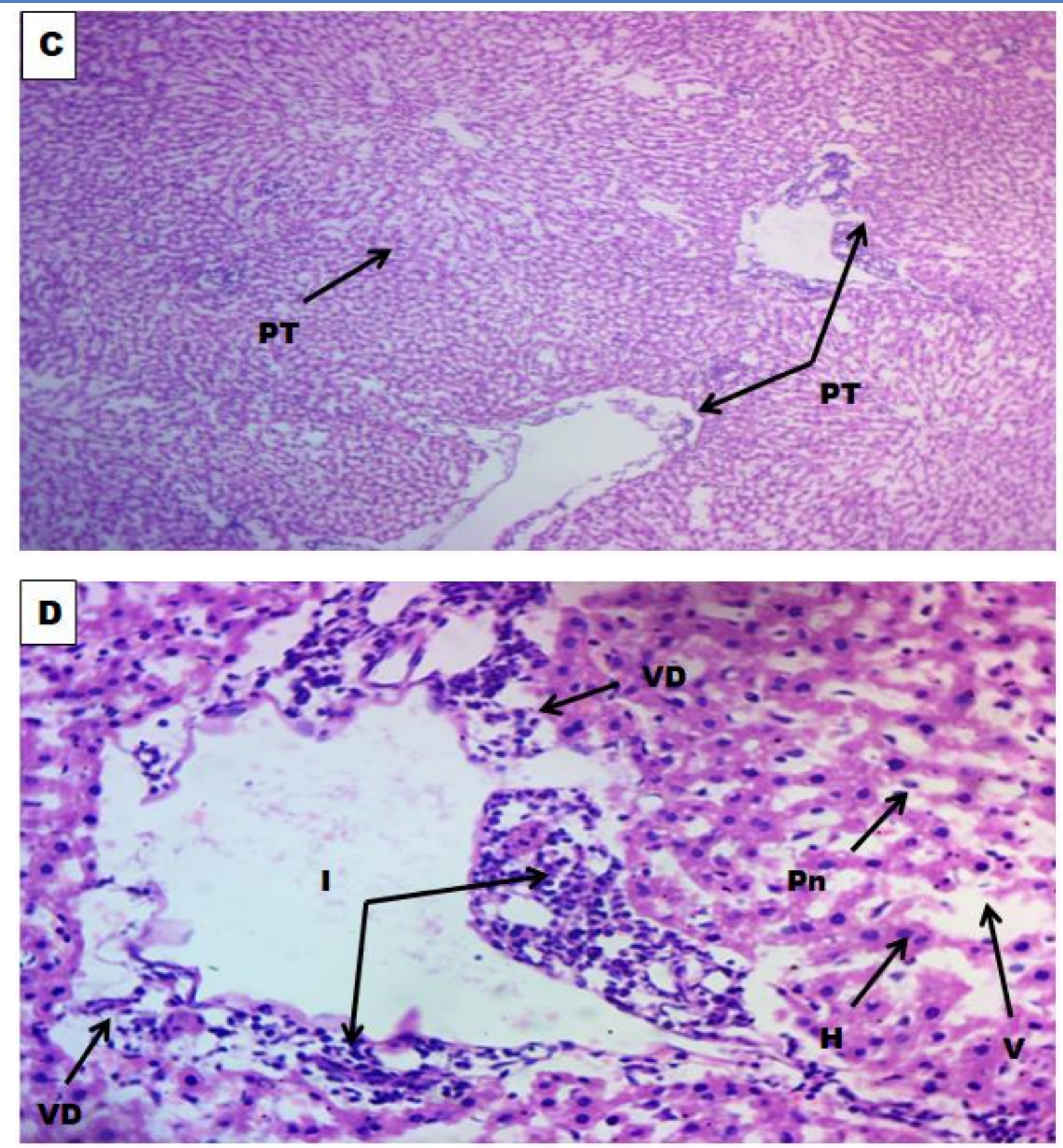

Figure II: Photomicrographs of Liver treated with $100 \mathrm{mg}$ of $\mathrm{AlCl}_{3}$ per $\mathrm{kg}$ body weight; $\mathrm{C}(\mathrm{x} 100)$ and $\mathrm{D}(\mathrm{x} 400)$ reveal areas of inflammation, vascular degeneration and vacuolation.

Key: Portal Triade (PT), Inflammation (I), Vascular Degeneration (VD), Pyknotic nucleaus (Pn), Hepatocytes (H), Vacuolation (V). 
Evaluation of the Protective Effect of Moringa oleifera Leaf Extract against Aluminium Induced Liver Damage in Male Albino Wistar Rats
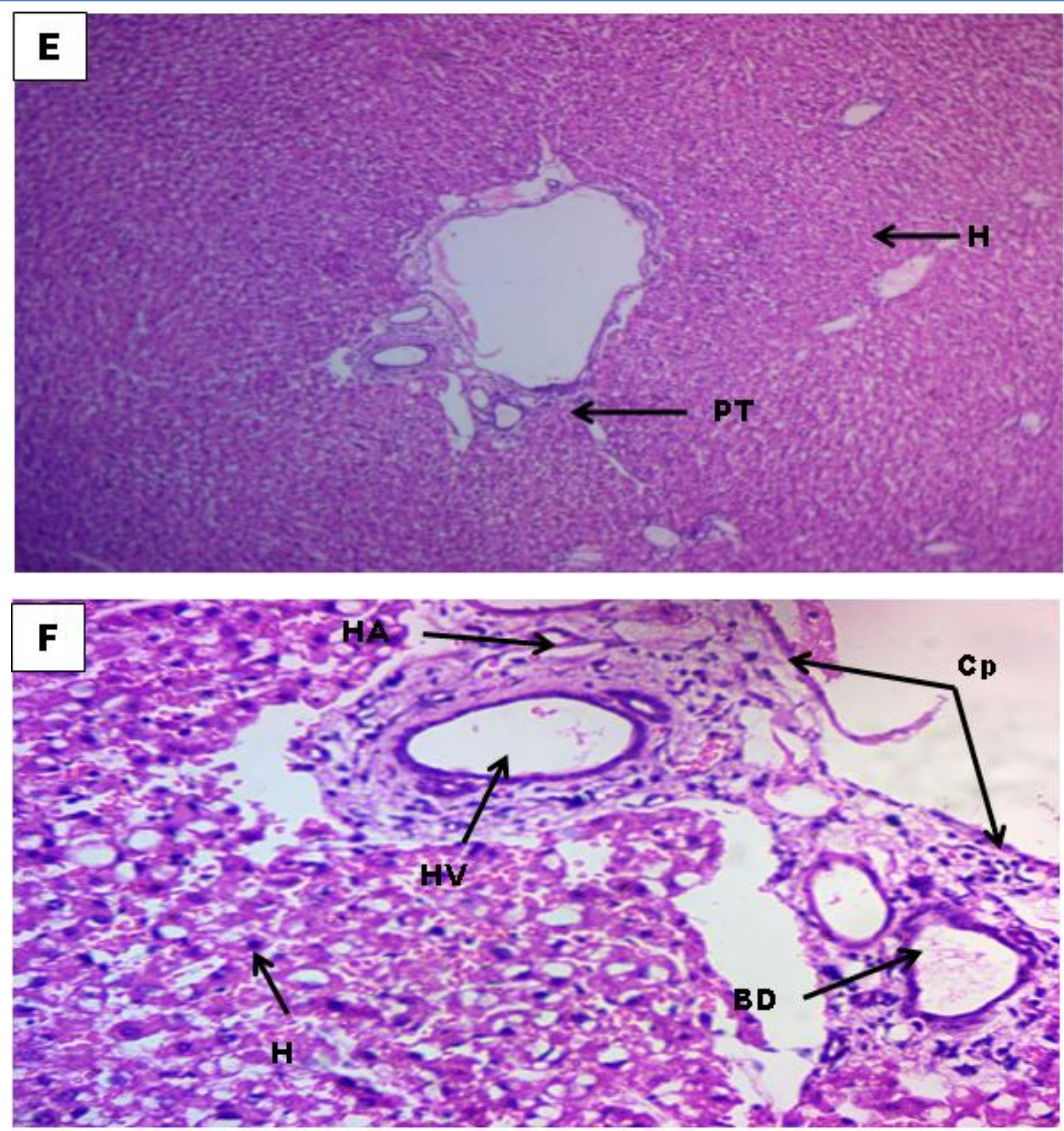

Figure III: Photomicrographs of liver treated with $100 \mathrm{mg} \mathrm{A} 1 \mathrm{Cl}_{3}$ and $300 \mathrm{mg}$ of Moringa oleifera per kg body weight at magnification $\mathrm{G}(\mathrm{x} 100)$ and $\mathrm{H}(\mathrm{x} 400)$ reveal that co-administration of ethanol leaf extract of Moringa oleifera had some modulatory effect on the Aluminium chloride induced alterations observed in Figure II.

Key: Portal Triade (PT), Hepatocytes (H), Hepatic Artery (HA), Hepatic Vein (HV), Cellular Proliferation (CP), Bile Duct (BD). 